\title{
Analiza wskazań ortodontycznych do leczenia operacyjnego przerostu pierścienia Waldeyera u dzieci w materiale Kliniki Otolaryngologii i Instytutu Stomatologii CMUJ w Krakowie
}

\author{
An analysis of indications orthodontic for surgical treatment of Waldeyer \\ ring hyperplasia in pediatric patients of the Otolaryngology and Stomatology \\ Department of the University Hospital of Krakow
}

\author{
Agnieszka Morawska ${ }^{1}$, Justyna Łyszczarz ${ }^{2}$, Jacek Składzieńn ${ }^{1}$ \\ ${ }^{1}$ Katedra i Klinika Otolaryngologii Collegium Medicum UJ w Krakowie \\ Kierownik: prof. dr hab. med. J. Składzień \\ ${ }^{2}$ Instytut Stomatologii Collegium Medicum Uniwersytetu Jagiellońskiego w Krakowie \\ Kierownik: dr hab. med. B.W. Loster
}

\begin{abstract}
Summary
Introduction. The lymphatic system of a child's throat has got a special role to play. It is the first line of contact for a developing organism with antigens in the environment. For a particular group of children Waldeyer ring hyperplasia is much bigger than it is for a usual group of patients. And that's what causes different illnesses Aim. The analysis of ortodonthic indications for surgical treatment of adenotomy and tonsillotomy. Material and method. The research was conducted on a group of hospitalized children in the Otorhinolaryngologic and in Stomatology Departament of Jagiellonian University Hospital in Krakow. The were treated for pathologic hypertrophy of adenoid and palatine tonsils. The analysis of occlusion disorder was carducted and the assessment of surgical and orthodontic treatment was performed. Results. In the years 2002-2006 in the Otorhinolaryngologic and in Stomatology Departament of Jagiellonian University Hospital in Krakow 24 children were being treated for pathologic hypertrophy of adenoid and/or palatine tonsils accompanied by an occlusion disorder. Conclusions. Adenotomy with or without tonsillotomy is one of the most frequently performed surgical operations on children. Throughout many years the indications for this procedure were infringed. Nowadays the operation is being performed mainly because of the rhinological and/or otological indications for the pathologic hypertrophy of adenoid and/or palatine tonsils. There is also another indication although it is less frequently used. This indication is an occlusion disorder which needs to be treated orthodontically.

Ha sła in deks owe: migdałek gardłowy, adenotomia, wada zgryzu

Ke y word s: adenoid, adenotomy, tonsillotomy, occlusion disorder
\end{abstract}

Otolaryngol Pol 2008; LXII (3): 272-277 @ 2008 by Polskie Towarzystwo Otorynolaryngologów - Chirurgów Głowy i Szyi

\section{WSTĘP}

Oddychanie przez nos, połączone z prawidłowym żuciem, połykaniem, funkcją i położeniem języka oraz warg warunkuje właściwą pracę mięśni stymulując wzrost i rozwój twarzoczaszki. Zmiana toru oddechowego z nosowego na ustny prowadzi do utrwalonego rozwarcia szpary ustnej oraz zachwiania równowagi między napięciem tkanek miękkich zewnątrz- i wewnątrzustnych, w wyniku czego dochodzi do rozwoju nieprawidłowości morfologicznych i czynnościowych twarzoczaszki. Obserwujemy wtedy tendencję do: protruzji siekaczy górnych, zwężenia szczęk, gotyckiego wysklepienia podniebienia, tyłozgryzu lub tyłożuchwia, zgryzu otwartego, zgryzu krzyżowego oraz hipotonii mięśnia okrężnego ust.

Częstym zjawiskiem towarzyszącym oddychaniu przy otwartych ustach jest przetrwanie niemowlęcego typu połykania. Polega on na połykaniu przy rozwartych ustach z językiem wsuniętym między wyrostki zębodołowe lub zęby. Zaburzenie to może być czynnikiem etiologicznym takich wad zgryzu, jak zgryz częściowy otwarty, przodozgryz lub tyłozgryz rzekomy (fot. 1) [1-3].

Autorzy nie zgłaszają konfliktu interesów. 


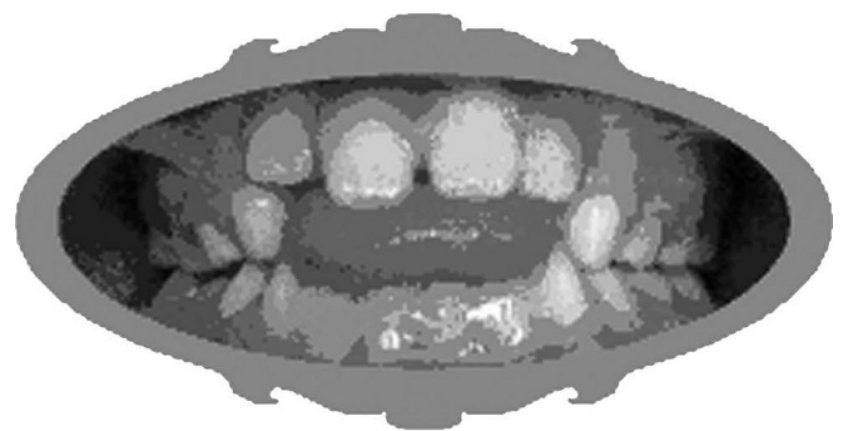

Fot. 1. Przetrwały niemowlęcy typ połykania. Zgryz otwarty częściowy, przedni

Klasyfikacja zaburzeń zgryzu oparta jest na podziale zaburzeń w odniesieniu do trzech płaszczyzn przestrzennych:

- strzałkowej (pośrodkowej), wobec której rozpatrujemy zwężenia, rozszerzenia i asymetrie (zaburzenia transwersalne);

- czołowej (oczodołowej), względem której rozpatrujemy zaburzenia przednio-tylne, tj. cofnięcia, wysunięcia (zaburzenia sagitalne);

- poziomej (horyzontalnej), względem której rozpatrujemy zaburzenia pionowe, tj. wydłużenia, skrócenia w obrębie dolnego odcinka twarzy (zaburzenia wertykalne).

\section{KLASYFIKACJA WAD ZGRYZU WG ORLIK-GRZYBOWSKIEJ}

I. Wady poprzeczne.

1. Zgryz krzyżowy: częściowy (przedni, boczny), całkowity (prawostronny, lewostronny).

2. Zgryz przewieszony: jednostronny, obustronny.

3. Boczne przemieszczenie żuchwy: czynnościowe, morfologiczne.

II. Wady przednio-tylne.

1. Tyłozgryz: całkowity, częściowy, rzekomy.

2. Tyłożuchwie: rzekomy, rzekomy.

3. Przodozgryz: całkowity, częściowy, rzekomy.

4. Przodożuchwie: czynnościowe, morfologiczne.

III. Wady pionowe.

1. Zgryz otwarty: całkowity, częściowy (przedni, boczny).

2. Zgryz głęboki: całkowity, częściowy, rzekomy.

3. Nadzgryz.

W zależności od wieku dziecka różne mogą być przyczyny upośledzonej drożności górnych dróg oddechowych. U noworodków najczęściej są to wady rozwojowe, u dzieci przerost tkanki chłonnej migdałów podniebiennych i migdałka gardłowego. Przyczyny przerostu pierścienia Waldeyera nie są do końca całkowicie wyjaśnione. W etiologii bierze się po uwagę reakcje immunologiczne,

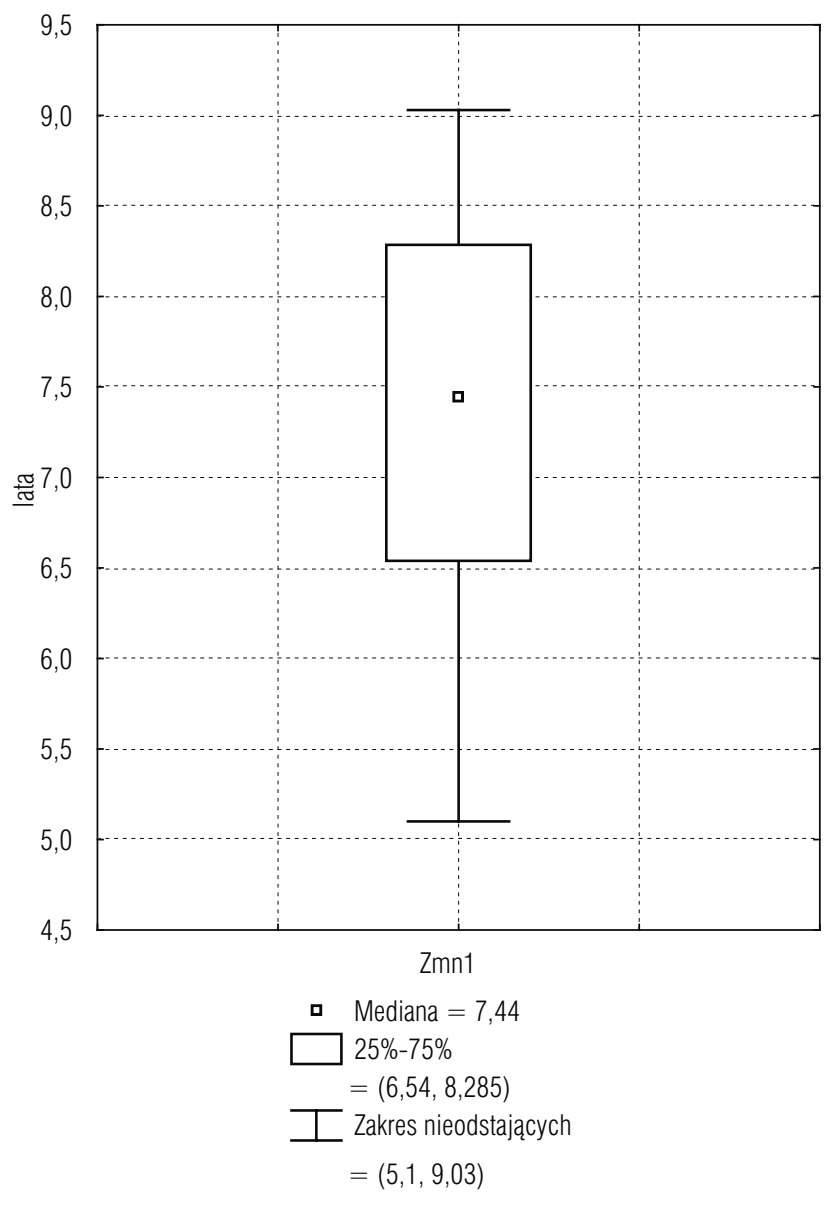

Ryc. 1. Struktura wiekowa badanych dzieci

czynniki hormonalne i genetyczne. Procesom przerostowym sprzyja występowanie przewlekłych nieswoistych procesów zapalnych, które prowadzą do powstania przerostu łącznotkankowego, metaplazji nabłonka i zaniku ośrodków namnażania limfocytów.

O rozpoznaniu przerostu migdałków decydują objawy kliniczne zebrane na podstawie wywiadu i przedmiotowego badania laryngologicznego [4-9].

\section{MATERIAŁ I METODA}

Analizą retrospektywną objęto dane uzyskane z dokumentacji medycznej chorych leczonych w latach 2002-2006 w Klinice Otolaryngologii oraz w Klinice Stomatologii CM UJ z patologicznym przerostem migdałka gardłowego i/lub migdałków podniebiennych ze współistniejącymi wadami zgryzu. Przeprowadzono szczegółowy wywiad oraz retrospektywną analizę stanu ogólnego i miejscowego dziecka. Oceniono rozrost migdałka gardłowego na podstawie rynoskopii tylnej i badania palpacyjnego. W badaniu wziernikowym 


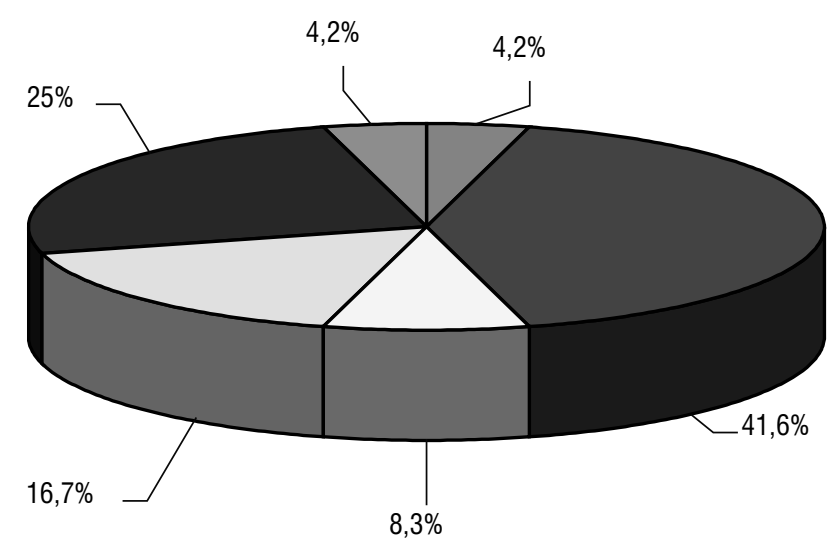

Ryc. 2. Rozkład poszczególnych wad zgryzu: 1 - tyłozgryz całkowity (41,6\%), 2 - tyłozgryz rzekomy (8,3\%), 3 - zgryz otwarty całkowity (4,2\%), 4 - zgryz otwarty częściowy przedni (16,7\%), 5 - zgryz krzyżowy (25\%), 7 - przodozgryz całkowity $(4,2 \%)$

nosogardła ustalono metodę półilościową wielkości migdałka gardłowego w stosunku do nozdrzy tylnych (I - tkanka adenoidalna sięgała do 1/3 choan, II - 1/2 choan, III $-2 / 3$ choan).

Badanie ortodontyczne $\mathrm{w}$ każdym przypadku obejmowało wywiad przeprowadzony z rodzicami, ocenę rysów twarzy, sposób oddychania, ocenę wad zgryzu oraz analizę zdjęć pantomograficznych i telerentgenogramów. Dzieci zakwalifikowane do badania charakteryzowały się występowaniem wad zgryzu wynikających z zaburzeń wyrostkowych i zębowych, a nie wad gnatycznych.

W latach 2002-2006 w Klinice Otolaryngologii oraz w Klinice Stomatologii CM UJ leczonych było łącznie 24 dzieci z patologicznym przerostem migdałka gardłowego i/lub migdałków podniebiennych ze współistniejącymi wadami zgryzu. Najmłodszy pacjent miał 5 lat, najstarszy 9 lat (ryc. 1). Średnia wieku wyniosła 7,33 lat.

\section{WYNIKI}

W grupie zakwalifikowanej do adenotomii z/lub bez tonsillotomii było 11 dziewcząt i 13 chłopców. Dzieci zakwalifikowane do badania posiadały wadę zgryzu wymagającą leczenia ortodontycznego oraz charakteryzowały się ustnym torem oddychania uwarunkowanym ograniczeniem drożności górnych dróg oddechowych z powodu przerostu układu chłonnego gardła. W badanej grupie stwierdzono występowanie następujących wad zgryzu: tyłozgryz całkowity ( $\mathrm{n}=$ 10 osób), tyłozgryz rzekomy ( $=2$ ), zgryz otwarty całkowity $(\mathrm{n}=1)$, zgryz otwarty częściowy przedni

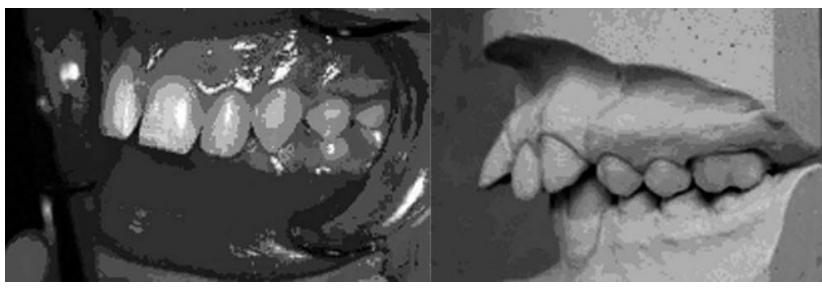

Fot. 2. Tyłozgryz całkowity z protruzją. Zdjęcie wewnątrzustne oraz model gipsowy

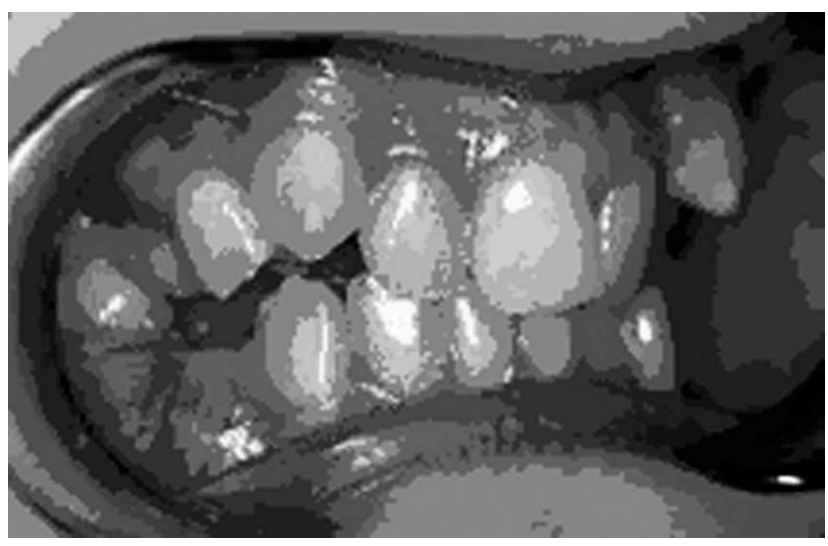

Fot. 3. Tyłozgryz całkowity z retruzje. Znacznego stopnia zwężenie szczęki spowodowało wystąpienie zgryzu krzyżowego i wad zębowych

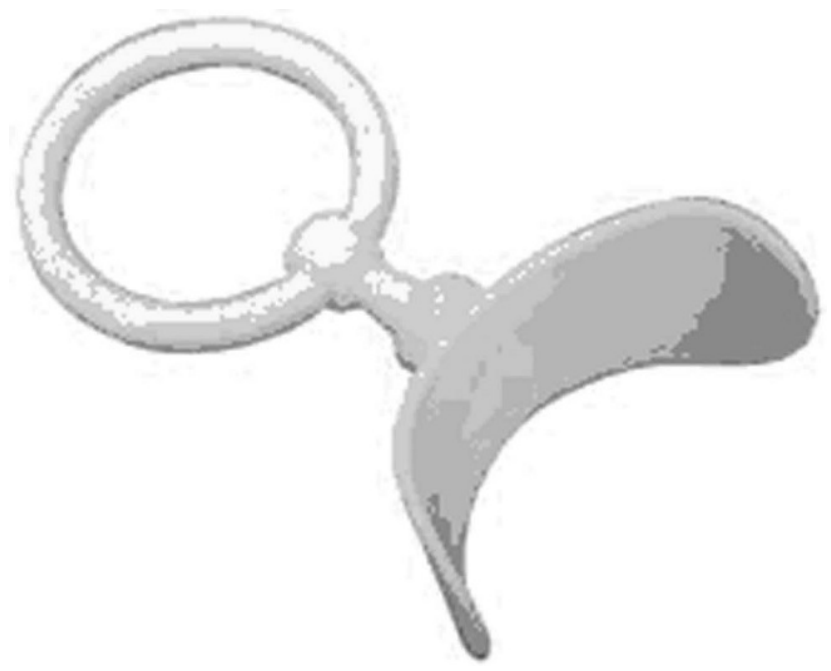

Fot. 4. Płytka przedsionkowa Schönherra dla dzieci

( $\mathrm{n}=4$ ), zgryz krzyżowy $(\mathrm{n}=6)$, przodozgryz całkowity $(\mathrm{n}=1)$. Rozkład wad zgryzu zilustrowano na rycinie 2.

W badaniu laryngologicznym stwierdzono u wszystkich 24 dzieci przerost migdałka gardłowego $(\mathrm{n}=17$ - II stopnia, $\mathrm{n}=7$ - III stopnia), a w przypadku 11 dzieci dodatkowo patologiczne powiększenie migdałków podniebiennych. 


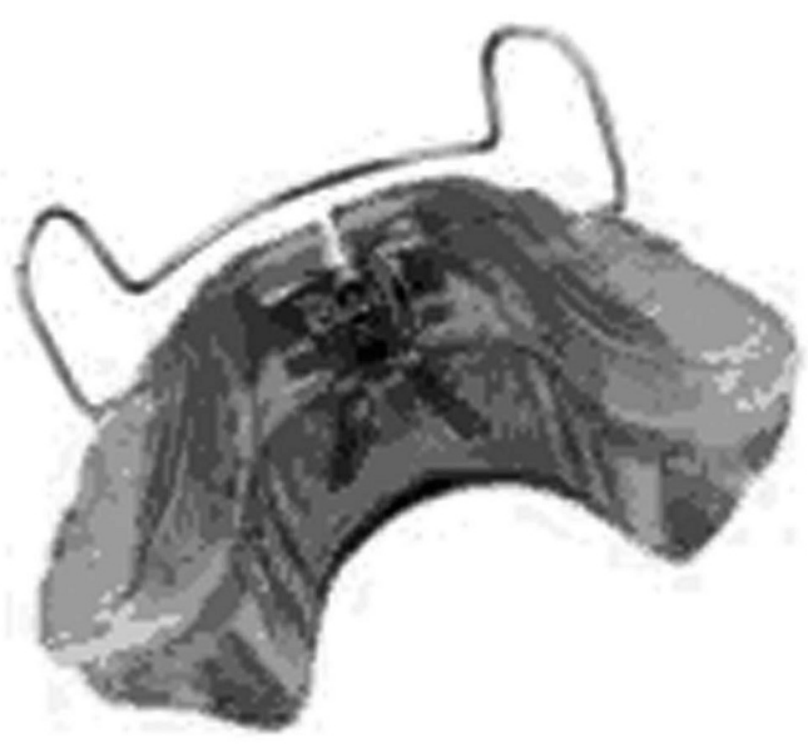

Fot. 5. Aparat blokowy ze śrubą do poszerzania

Najczęściej występującą wadą zgryzu był tyłozgryz. W 8 z 10 przypadków był on połączony z protruzją siekaczy (fot. 2).

Podstawowym wadom zgryzu w 17 przypadkach (70,8\%) towarzyszyło zwężenie szczęki oraz współistniejące wady zębowe (fot. 3).

W grupie dzieci hospitalizowanych z powodu patologicznego przerostu migdałka gardłowego wykonano w 75\% adenotomię. Zabieg wykonano w znieczuleniu ogólnym, z pomocą noża Beckmanna. U 25\% młodych pacjentów wykonano adenotomię i tonsillotomię.

Usunięcie przerosłej tkanki chłonnej przywróciło u $62,5 \%$ (15 przypadków) chorych nosowy tor oddechu oraz pozwoliło na zakwalifikowanie do leczenia ortodontycznego wady zgryzu. U 9 dzieci po 4 miesiącach obserwacji nie stwierdzono powrotu do prawidłowego toru oddychania. W tej grupie ustny tor oddychania utrwalił się jako nawykowy i przywrócenie właściwego procesu oddychania wymagało zastosowania ćwiczeń i aparatów redukujących sposób oddychania. Zalecono ćwiczenia wzmacniające mięsień okrężny ust oraz ćwiczenia mięśniowe dostosowane do poszczególnych wad zgryzu. Po 6 miesiącach ćwiczeń u dalszych 7 dzieci uzyskano powrót do nosowego toru oddychania. W leczeniu wad zgryzu posłużono się aparatami ortodontycznymi ruchomymi. U wszystkich dzieci leczenie zostało rozpoczęte od zastosowania standardowej płytki przedsionkowej rozmiarem dopasowanej do wieku pacjenta (fot. 4).

Zastosowanie płytki przedsionkowej miało na celu ograniczenie dopływu powietrza przez usta, wzmoc-

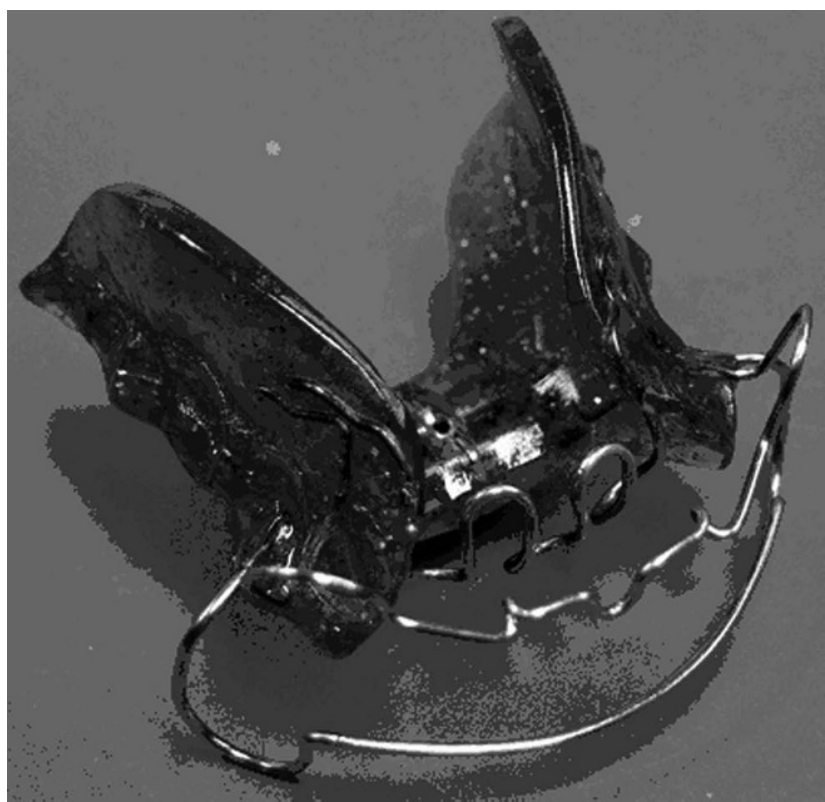

Fot. 6. Aparat blokowy z zaporą dla języka

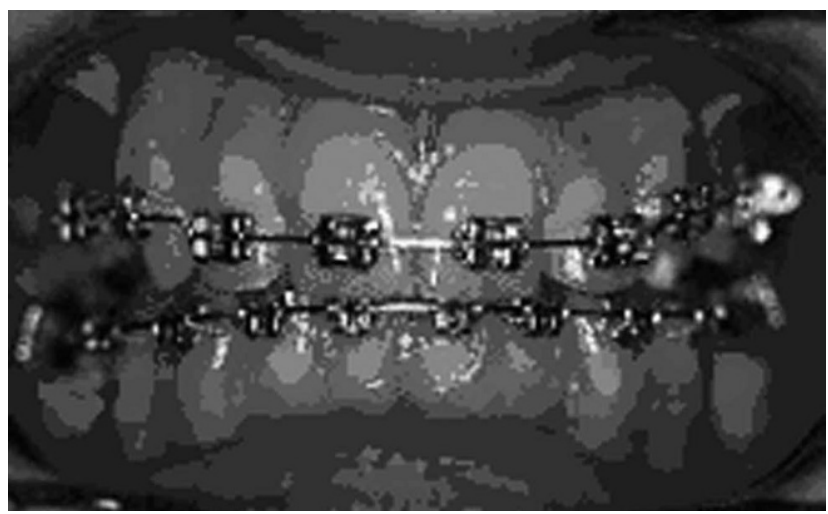

Fot. 7. Aparat stały

nienie mięśnia okrężnego ust oraz przygotowanie do dalszego leczenia ortodontycznego.

W dalszej części leczenia zastosowano aparaty jedno- i obuszczękowe. Do leczenia tyłozgryzów, przodozgryzu i zgryzów otwartych zastosowano aparaty blokowe (fot. 5).

W przypadku współistnienia dysfunkcji połykania w aparatach zastosowano dodatkowo zapory dla języka służące ćwiczeniu języka i uniemożliwiające jego wciskanie między łuki zębowe w akcie połykania (fot. 6).

W leczeniu zgryzów krzyżowych stosowano płytkę Schwarza górną w celu poszerzenia szczęki lub również aparat blokowy.

W wyniku leczenia ortodontycznego uzyskano normę zgryzową i poprawę rysów twarzy u 22 pacjentów stosując aparaty czynne lub czynno-czynnościowe. W dwóch przypadkach tyłozgryzów, któ- 
rym towarzyszył pośredni test czynnościowy (przez wysunięcie żuchwy uzyskiwano poprawę warunków zgryzowych, natomiast rysy twarzy ulegały pogorszeniu) oraz znacznego stopnia stłoczenie zębów podjęto leczenie z ekstrakcją dwóch zębów przedtrzonowych w szczęce i leczenie aparatami stałymi górnym i dolnym (fot. 7).

Średni czas leczenia ortodontycznego wyniósł 1 rok i 7 miesięcy. Pacjenci nadal znajdują się pod okresową kontrolą ortodontyczną w celu oceny utrzymania efektów leczenia.

\section{DYSKUSJA}

Układ chłonny gardła u dzieci odgrywa szczególną rolę - jest pierwszą linią kontaktu rozwijającego się organizmu z antygenami występującymi w otaczającym środowisku. U pewnej grupy dzieci, przerost pierścienia Waldeyera wykracza poza granice wyznaczone fizjologicznymi normami, stając się przyczyną chorób.

Adenotomia z/lub bez tonsillotomii jest jednym z najczęściej wykonywanych zabiegów chirurgicznych $\mathrm{w}$ tej grupie wiekowej. Od wielu lat zabiegi usuwania migdałków wywołują wiele kontrowersji dotyczących wskazań do zabiegów oraz metod operacyjnych. $\mathrm{Na}$ przestrzeni lat wskazania do tych procedur uległy zmianom i ograniczeniom. W pierwszej połowie XX wieku były one powszechnie wykonywane, a wskazania do adenotomii, tonsillotomii, tonsillektomii były bardzo szerokie i wiązały się głównie z nawracającymi stanami zapalnymi gardła. W późniejszych latach, w związku z powszechnym wprowadzeniem antybiotyków do leczenia zakażeń gardła, wskazania te zostały częściowo ograniczone [10, 11]. Poznanie roli migdałków w układzie odpornościowym przyczyniło się do kolejnej zmiany kryteriów kwalifikacji do zabiegów. Obecnie zabieg wykonuje się głównie ze wskazań rynologicznych i/lub otiatrycznych następstw przerośniętego migdałka gardłowego (Cauvenberge i in. 1995, Deutsh 1996, Takahashi i wsp. 1997, Vanderberg i Heatley 1997, Brodsky 1999) [12, 13]. Rzadszym wskazaniem są wynikające z przerostu tkanki chłonnej gardła wady zgryzu wymagające leczenia ortodontycznego. Rola adenotomii z/lub bez tonsillotomii w leczeniu wad zgryzu współistniejących z przerostem migdałka gardłowego została w pełni potwierdzona (Brodsky 1989, Hultcrantz i wsp. 1991, Cauvenberge i wsp. 1995).

W cytowanych pracach u większości pacjentów nastąpiła normalizacja zgryzu po upływie 2 lat od zabiegu, przy czym zdecydowanie lepsze wyniki obserwowano w grupie dzieci, które były operowane przed ukończeniem 6. roku życia. Podobny okres potrzebny do uzyskania normy zgryzowej obserwowaliśmy u naszych pacjentów, a najlepsze wyniki leczenia dotyczyły dzieci w okresie wczesnoszkolnym $[14,15]$.

Potwierdzając doniesienia $\mathrm{z}$ ostatnich lat, należy podkreślić, że ważne jest wczesne rozpoznanie zaburzeń toru oddychania, wykrycie ich przyczyn oraz przywrócenie prawidłowego toru oddechowego i odpowiednio wczesne rozpoczęcie leczenia ortodontycznego, a uzyskanie trwałych wyników jest możliwe tylko w przypadku prawidłowego funkcjonowania całego układu stomatognatycznego.

\section{WNIOSKI}

1. Patologiczny przerost migdałka gardłowego, współistniejący ze zmianami chorobowymi w innych narządach powstałymi w wyniku jego powiększenia są podstawowymi wskazaniami do zabiegu operacyjnego.

2. Istnieje zależność między wielkością migdałków a tendencją do oddychania przez usta i powstawania wad zgryzu.

3. Zastosowanie wielu rodzajów aparatów ortodontycznych wiąże się z koniecznością oddychania przy zamkniętych ustach, dlatego niezbędne jest prawidłowe i wczesne zdiagnozowanie oraz leczenie przyczyn niedrożności nosa.

4. Uzyskanie trwałych wyników leczenia ortodontycznego jest uwarunkowane prawidłowym funkcjonowaniem całego układu stomatognatycznego, w tym również prawidłową funkcją oddychania.

\section{PIŚMIENNICTWO}

1. Bielawska H. Rozwój fizyczny i wady zgryzu u dzieci oddychających przez usta. Pediatr Pol 1998; 73(12): 12651271.

2. Casselbrant ML. What is wrong in chronic adenoiditis/tonsillitis anatomical considerations Int J Pediatr Otorhinolaryngol 1999; 49: S133-S135.

3. Faria P, Ruellas A, Matsumoto M, Anselmo-Lima F, Periera F. Dentofacial Morphology of Mouth Breathing Children. Braz Dent J 2202: 13(2): 129-132.

4. Gates GA, Avery CA, Priho DA. Effect of adenoidectomy up on children with chronic otitis media with effusion. Laryngoscope 98 1988; 58-63.

5. Faden H, Waz M, Bernstein J, Brodsky L, Stanievich J, Ogra PL. Nasopharyngeal flora in the first three years of life in normal and otitis-prone children. Ann Otol Rhinol Laryngol 1991; 100: 612-615. 
6. Dominik K. Zarys ortopededii szczękowej, Wydawnictwo Uniwersytetu Jagiellońskiego, Wydanie VIII, Kraków 1999. Casselbrant ML. What is wrong in chronic adenoiditis/tonsillitis anatomical considerations Int J Pediatr Otorhinolaryngol 1999; 49: S133-S135.

7. Vinke JG, Fokken WJ. The role of the adenoid in allergic sensitization Int J Pediatr Otorhinolaryngol 199; 49: S145S149.

8. Winther B, Innes DJ. The human adenoid. A morphologic study. Arch Otolaryngol Head Neck Surg 1994; 120(2): 144-149.

9. Mc Namara Jr JA: Influence of respiratory pattern on craniofacial groth. Angle Orthod 1981; 51: 269-300.

10. Śmiech-Słomkowska G. Znaczenie sposobu oddychania w profilaktyce ortodontycznej. Mag Stom 1994; 4: 27-28.

11. Karłowska I. Zarys współczesnej ortodoncji, Wydawnictwo Lekarskie PZWL, Warszawa 2002.

12. Morawska A, Baran Z, Wiatr M, Składzień J. Analiza wskazań i wyników leczenia operacyjnego przerostu pierścienia Waldeyera u dzieci. Otorynolaryngologia Mediton, Łódź 2007; 4: 194-199.

13. Hultcrantz E.: The influence of tonsillar obstruction and tonsillectomy on facial growth and dental arch morphology. Int J Ped Otorhinolaryngol 1991; 22: 125-134.
14. Brodsky L, Frankel S, Gorfien J, Rossman J, Noble B. The role of dendritic cells in the development of chronic tonsillar disease in children. Acta Otolaryngol 1996; 523: 98-100.

15. Linder-Aronson S. Normalization of incisor position after adenoidectomy. Am J Ortodontol 1993; 103(5): 412-426.

16. Bernstein JM. Waldeyer's ring and otitis media. The nasopharyngeal tonsil and otitis media. Int J Pediatr Otorhinolaryngol 1999; 49: S127-S132.

Adres autora:

lek. med. Agnieszka Morawska

Klinika Otolaryngologii CMUJ w Krakowie

ul. Śniadeckich 2

tel. (+12) 4247900

fax (+12) 4247925

e-mail: agnieszkamorawska@op.pl

Pracę nadesłano: 25.03.2008 r. 